University of Nebraska - Lincoln

DigitalCommons@University of Nebraska - Lincoln

USDA Forest Service / UNL Faculty Publications U.S. Department of Agriculture: Forest Service -National Agroforestry Center

2012

\title{
Co-production of electricity and ethanol, process economics of value prior combustion
}

\author{
Trevor Treasure \\ North Carolina State University, trevor_treasure@ncsu.edu \\ R. Gonzalez \\ North Carolina State University, ronalds.gonzalez@gmail.com \\ Richard Venditti \\ North Carolina State University, richard_venditti@ncsu.edu \\ Y. Pu \\ North Carolina State University \\ H. Jameel \\ North Carolina State University \\ See next page for additional authors
}

Follow this and additional works at: https://digitalcommons.unl.edu/usdafsfacpub

Treasure, Trevor; Gonzalez, R.; Venditti, Richard; Pu, Y.; Jameel, H.; Kelley, Steve; and Prestemon, Jeffrey, "Co-production of electricity and ethanol, process economics of value prior combustion" (2012). USDA Forest Service / UNL Faculty Publications. 242.

https://digitalcommons.unl.edu/usdafsfacpub/242

This Article is brought to you for free and open access by the U.S. Department of Agriculture: Forest Service -National Agroforestry Center at DigitalCommons@University of Nebraska - Lincoln. It has been accepted for inclusion in USDA Forest Service / UNL Faculty Publications by an authorized administrator of DigitalCommons@University of Nebraska - Lincoln. 


\section{Authors}

Trevor Treasure, R. Gonzalez, Richard Venditti, Y. Pu, H. Jameel, Steve Kelley, and Jeffrey Prestemon 


\title{
Co-production of electricity and ethanol, process economics of value prior combustion
}

\author{
T. Treasure ${ }^{a}$, R. Gonzalez ${ }^{a, *}$, R. Venditti ${ }^{a}$, Y. Pu ${ }^{a}$, H. Jameel ${ }^{a}$, S. Kelley ${ }^{a}$, Jeffrey Prestemon ${ }^{b}$ \\ ${ }^{a}$ Department of Forest Biomaterials, North Carolina State University, Raleigh, NC 27695, United States \\ ${ }^{\mathrm{b}}$ USDA Forest Service, United States
}

\section{A R T I C L E I N F O}

\section{Article history:}

Received 10 January 2012

Received in revised form 4 April 2012

Accepted 5 April 2012

Available online 26 June 2012

\section{Keywords:}

Value prior to combustion

Power

Ethanol

Hemicellulose

Autohydrolysis

Softwood

Hardwood

Minimum ethanol selling price

\begin{abstract}
A B S T R A C T
A process economic analysis of co-producing bioethanol and electricity (value prior to combustion) from mixed southern hardwood and southern yellow pine is presented. Bioethanol is produced by extracting carbohydrates from wood via autohydrolysis, membrane separation of byproducts, enzymatic hydrolysis of extracted oligomers and fermentation to ethanol. The residual solids after autohydrolysis are pressed and burned in a power boiler to generate steam and electricity. A base case scenario of biomass combustion to produce electricity is presented as a reference to understand the basics of bio-power generation economics. For the base case, minimum electricity revenue of $\$ 70-\$ 96 / \mathrm{MWh}$ must be realized to achieve a $6-12 \%$ internal rate of return. In the alternative co-production cases, the ethanol facility is treated as a separate business entity that purchases power and steam from the biomass power plant. Minimum ethanol revenue required to achieve a $12 \%$ internal rate of return was estimated to be $\$ 0.84-\$ 1.05 / 1$ for hardwood and $\$ 0.74-\$ 0.85 / 1$ for softwood. Based on current market conditions and an assumed future ethanol selling price of $\$ 0.65 / 1$, the co-production of cellulosic bioethanol and power does not produce financeable returns. A risk analysis indicates that there is a probability of $26.6 \%$ to achieve an internal rate of return equal or higher than $12 \%$. It is suggested that focus be placed on improving yield and reducing CAPEX before this technology can be applied commercially. This modeling approach is a robust method to evaluate economic feasibility of integrated production of bio-power and other products based on extracted hemicellulose.
\end{abstract}

(c) 2012 Elsevier Ltd. All rights reserved.

\section{Introduction}

The effective conversion of cellulosic biomass into different forms of energy has been the target for many researchers in the last decades [1-7]. Although several pathways have been developed (biomass to power, lignocellulosic biomass to ethanol, etc.) $[1,2,5,8-10]$, very few technologies meet the key requirements to become commercial: being both profitable under current market conditions and environmentally friendly. The success of corn ethanol in the US and sugar cane ethanol in Brazil has been widely discussed [1,11-14]. Nevertheless, it is important to note that the economics of both processes benefit from the commercialization of byproducts, as well as a continued improvement in the efficiency of the conversion process (efficient conversion of the feedstock into ethanol and different byproducts) $[1,10,15]$. Production of goods in addition to ethanol from lignocellulosic biomass may increase profitability and reduce investment risks which will attract investors. This paper presents a process economic analysis of co-producing cellulosic ethanol and electrical power. This production process evaluated is accomplished via autohydrolysis

\footnotetext{
* Corresponding author. Tel.: +1 9198025219.

E-mail address: ronalds.gonzalez@gmail.com (R. Gonzalez).
}

and extraction of hemicelluloses (carbohydrate extraction for alcohol production) and burning the residues for power generation; a process termed value prior to combustion (VPC).

The hot-water extraction process, also known as autohydrolysis, can extract hemicellulose oligomers and monomers (mainly xylooligmers with different degrees of polymerization) from wood while leaving other components intact [16-20]. Temperature and reactor residence time are critical parameters to minimize sugar degradation and extraction yield. During hot-water extraction, acids are produced by the hydrolysis of hemicelluloses [18]. These acids, coupled with the dissolution of extractives in the biomass, cause the liquor $\mathrm{pH}$ to drop and effectively self-catalyze the hydrolysis process [21]. The sugar degradation products (furfural and hydroxymethylfurfural) are easily volatilized and may result in a loss of yield. The extracted xylose and other hemicellulose sugars can undergo fermentation to ethanol and can be considered a potential renewable resource for bio-based fuels [22,23]. Although we have focused on fermentation of extracted sugars to produce ethanol, hemicellulosic sugars can also be used to produce biodegradable plastics and chemicals that are currently derived from petroleum $[18,19,24]$. The residues after hot water extraction can be burned to produce steam and electricity or alternatively can be used as a raw material for wood and paper products. 
The concept of liquid fuel and power production from the same feedstock has several advantages in comparison to traditional second generation ethanol production technologies that are only focused on producing cellulosic ethanol or traditional bio-power platforms for electricity generation. Previous studies have indicated that liquid biofuel and bio-power production could profitably co-exist in an integrated process as technology improvement occurs [25-27]. From an efficiency point of view, hot water extraction removes components of the feedstock (hemicelluloses) that have low heating value but can potentially be converted to valuable by-products such as ethanol [28]. By removing the low heating value components from the raw material, the heating value of the residual solids is actually higher per unit mass and therefore a smaller boiler can be used to produce the same amount of power. From a revenue point of view, VPC diversifies the portfolio of products and reduces risk of the biorefinery in regards to fluctuations in main product selling prices. Previous research efforts in co-production of power and ethanol concluded that high capital investment and high enzyme costs limit the potential of this combined production process [28]. However, in comparison to traditional second generation cellulosic ethanol technologies, the cost of enzyme hydrolysis may be substantially lower since enzymes are only being used on soluble oligosaccharides which hydrolyze in less time with less enzyme than hydrolysis of insoluble pretreated lignocellulosics used in traditional second generation technologies. The co-production of high value bio-based products from the extracted hemicelluloses would also increase the profitability of combined production processes and may lead to greater diversity in product portfolio as the technology for bio-based product production becomes more mature [29].

The aim of this paper is to present the economics of co-producing power and lignocellulosic ethanol in an integrated process using southern mixed hardwood and southern yellow pine as feedstocks. The economics of standalone power generation from biomass in a greenfield plant is explored first and represents a base case analysis. The following economic indicators were determined to gauge the economic performance of the base case and proposed cases: internal rate of return (IRR), net present value (NPV), payback period, and minimum power selling price (to achieve a specific internal rate of return). After developing the base case, the proposed scenario involving biomass autohydrolysis and sugar extraction to produce ethanol while burning the residual solids was developed and analyzed. The discussion provides novel information needed to understand the tradeoff between producing power and ethanol in an integrated conversion process.

\section{Materials and methods}

In order to offer a guide for the information provided in this paper a brief description of each section is presented here. The "Feedstock" section provides the chemical composition, moisture content and delivered cost of the raw materials. The "Basis for Evaluation" section establishes the framework for comparison across the paper; defining the base case (power generation only) and alternative case (power and ethanol production). The "Proposed Pathway" section describes the integrated process for power and ethanol production in more detail by identifying the major unit operations as well as process conditions. The "Conversion Factors" section deals with wood component yields through autohydrolysis and defines the composition of both extraction liquor and solid residues. The process modeling framework, including software used, inputs, and constraints, is presented in the "Process Simulation" section. Within the "Economics Analysis" section, the variables used for the estimation of the economic indicators and the methods to estimate cost drivers are presented.

\subsection{Feedstock}

Feedstocks used in this analysis are softwood (southern yellow pine) and hardwood (natural southern mixed hardwood) in the form of forest residues (also called hog fuel). The moisture content estimated for hog fuel was about $40 \%$ [30-32].

The chemical composition of the feedstock (softwood and hardwood) used for this study is a normalized version of compositional analysis data collected in the lab (Table 1). The original compositional analysis was determined at the Department of Forest Biomaterials at North Carolina State University and is explored in greater detail by Pu et al. [21]. Proportional normalization of the feedstock composition was performed to satisfy mass balance constraints within the process model.

\subsection{Basis for evaluation}

As previously mentioned, this paper presents the economics of an integrated process producing power and ethanol. The economics of standalone power generation from biomass is explored first. In an alternative case, power and ethanol are produced in the same facility. For the economic analysis, a greenfield concept was used. Further explanation for each case is presented next.

\subsubsection{Base case}

Power generation from biomass is evaluated in the base case for softwood and hardwood, separately. The conversion process of a greenfield plant was simulated in WinGEMS [33] and the economics in an Excel spreadsheet. An annual input of 500,000 dry short tons (abbreviated as BDT) (or 453,592 dry metric tons), is fed into the system to achieve a power generation rate of $\sim 72 \mathrm{MW}$. The facility was assumed to operate for 350 days per year which results in $\sim 605 \mathrm{GWh}$ of power produced annually.

\subsubsection{Alternative case}

In the alternative case, power and ethanol are co-produced in an integrated plant. The model was built in order to recalculate the amount of feedstock required to produce $\sim 72 \mathrm{MW}$. The amount of biomass fed to the facility is higher than the Base Case because some of the material that was previously burned to produce electricity is now being converted to ethanol. A total of six alternative cases were evaluated as outlined in Table 2 . For all the cases, the model estimates the amount of feedstock required to produce $95 \%$ of the power capacity ( $\sim 72 \mathrm{MW})$, an additional production capacity of $5 \%$ has been assumed for capital investment (CAPEX) estimation. The same excess capacity and additional CAPEX requirement are also assumed in the base case.

\subsection{Proposed pathway}

The proposed pathway for integrated power and cellulosic ethanol production is illustrated in Fig. 1. Lignocellulosic biomass is fed into the autohydrolysis reactor for $1 \mathrm{~h}$ residence time at the specified temperature (Table 2 ). For all alternative cases, $13 \%$ of the incoming feedstock is assumed to contain a share of under-/

Table 1

Chemical composition of softwood and hardwood feedstocks.

\begin{tabular}{lll}
\hline Component & Hardwood (\%) & Softwood (\%) \\
\hline Lignin & 27 & 29 \\
Glucan & 46 & 46 \\
Hexan & 4 & 14 \\
Xylan & 19 & 7 \\
Extractives & 3 & 3 \\
Ash & 1 & 1 \\
\hline
\end{tabular}


Table 2

Alternative cases in power and ethanol production.

\begin{tabular}{|c|c|c|c|c|c|c|}
\hline Case & I & II & III & IV & $\mathrm{V}$ & VI \\
\hline Feedstock & Hardwood & Hardwood & Hardwood & Softwood & Softwood & Softwood \\
\hline Autohydrolysis temperature $\left({ }^{\circ} \mathrm{C}\right)$ & 160 & 170 & 180 & 160 & 170 & 180 \\
\hline Reaction time & $1 \mathrm{~h}$ & $1 \mathrm{~h}$ & $1 \mathrm{~h}$ & $1 \mathrm{~h}$ & $1 \mathrm{~h}$ & $1 \mathrm{~h}$ \\
\hline Product & Power & Power & Power & Power & Power & Power \\
\hline Co-product & Ethanol & Ethanol & Ethanol & Ethanol & Ethanol & Ethanol \\
\hline
\end{tabular}

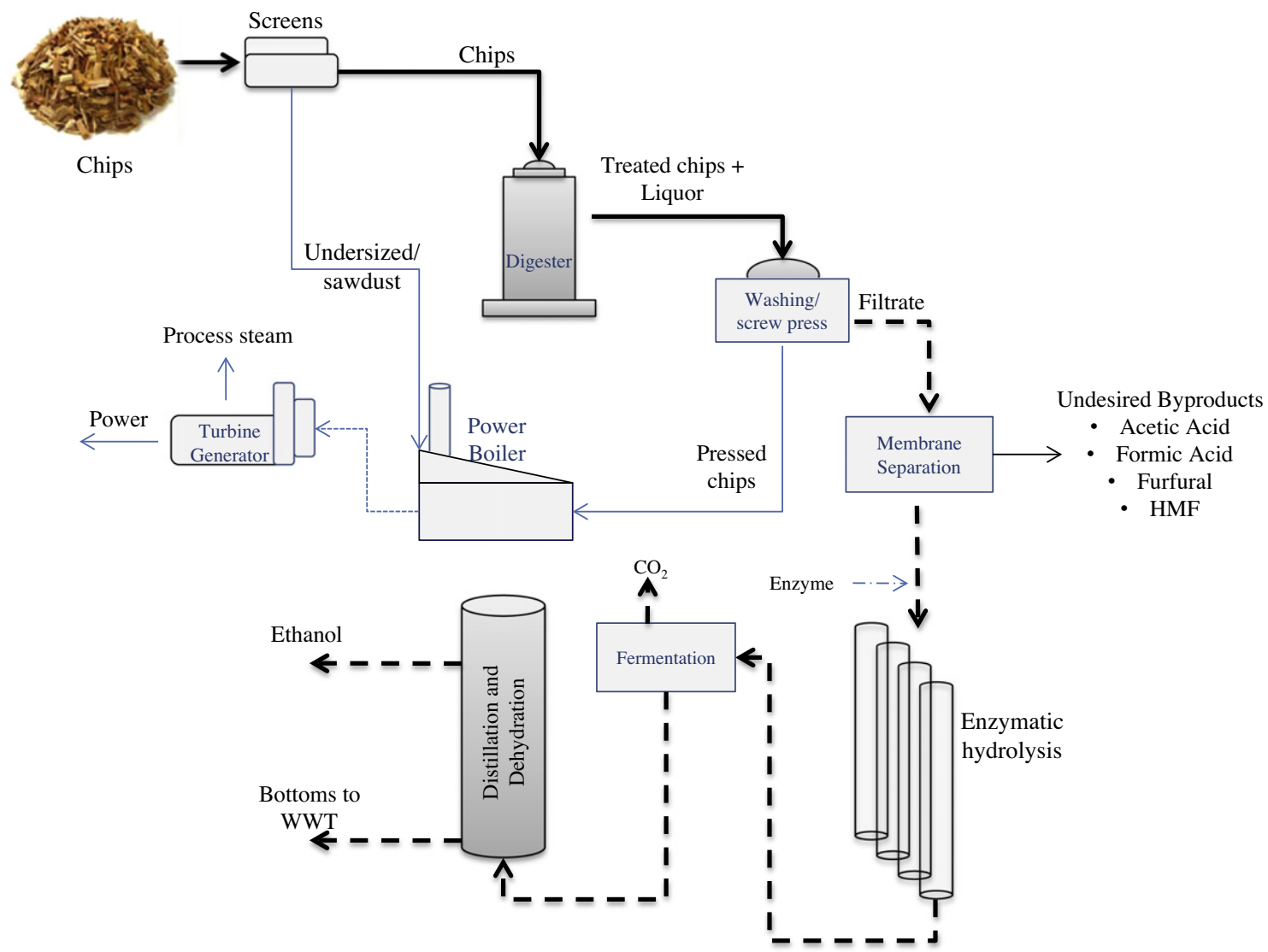

Fig. 1. Proposed integrated system for power and lignocellulosic ethanol production.

over-sized chips and generated saw dust that would not process well in the water hydrolysis reactor and is therefore sent directly to the combustor in the power plant (this might also include high heating value materials usually purchased by bio-power companies as treated and dry wood). Thus, $87 \%$ of the total feedstock brought into the facility is fed to the water hydrolysis reactor for sugar extraction. After autohydrolysis, the slurry is passed through a washing-screw press system to recover dissolved carbohydrates and reduce the moisture content of the solid residue to $40 \%$ before it is sent to the combustor for power generation. In this stage of processing, it is assumed that $91 \%$ of the sugars are recovered in the filtrate for conditioning and fermentation to ethanol during washing and that $9 \%$ of the dissolved carbohydrates are burned, as opposed to being conditioned and fermented to produce ethanol. The filtrate, containing both monomeric and oligomeric carbohydrates as well as dissolved wood solids, is passed through a membrane system to remove undesired products generated during autohydrolysis such as furfural, hydroxymethylfurfural, acetic acid and formic acid. It was assumed that $\sim 90 \%$ of the undesired byproducts are removed in the membrane system although laboratory studies have reported higher separation efficiencies [18]. Oligomeric sugars are then hydrolyzed using enzymes. The resulting filtrate ( $\sim 16 \%$ sugar concentration, water removal by means of membrane filtration) is fermented and distilled to produce anhydrous fuel grade ethanol. Conversion efficiency during enzymatic hydrolysis was $100 \%$ for pentoses (five carbon sugar) and hexoses (six carbon sugars) with a total residence time of $48 \mathrm{~h} ; 48 \mathrm{~h}$ is a conservative estimate as this residence time is typical for enzymatic hydrolysis of insoluble lignocellulosic substrates and therefore may be significantly less for the soluble oligomeric sugar stream in this process. Conversion efficiency used for fermentation was $95 \%$ for hexoses and $80 \%$ for pentoses with a total residence time of $36 \mathrm{~h}$. Fermentation experiments were not performed in the lab and modeling conversion factors were assumed using data from previous reports $[1,34]$.

\subsection{Mass balance of extract and residues}

After the autohydrolysis reactions take place, pentoses and hexoses are partially extracted into the liquid phase. Degradation of sugars into non-desirable products also occurs (furfural, hydroxymethylfurfural, acetic acid and formic acid). These products are not desirable because they constitute a yield loss and can inhibit downstream fermentation. As more degradation products are 
formed the material balance data collected in the lab becomes more open. Presumably, this results from volatilization of degradation products. To account for this lack of material balance closure, a "Volatiles" component was incorporated into the dissolved solids stream structure of the process model. Dry matter loss to volatiles for hardwood is larger compared to softwood and increases as temperature increases; as the autohydrolysis temperature increases from $160{ }^{\circ} \mathrm{C}$ to $180^{\circ} \mathrm{C}$, the amount of dry hardwood that degrades to a volatile component increases from $6.3 \%$ to $17.5 \%$ [21]. The complete mass balances for hardwood at $160^{\circ} \mathrm{C}, 170{ }^{\circ} \mathrm{C}$, and $180^{\circ} \mathrm{C}$ are illustrated in Table 3. The mass balances are reported on a 1000 oven dry $\mathrm{kg}$ of raw material basis.

The amount of material extracted from hardwood, at all temperatures, was more than softwood. The amount of material degraded to unspecified volatiles is lower for softwood compared to hardwood; as the autohydrolysis temperature for softwood increases from $160{ }^{\circ} \mathrm{C}$ to $180^{\circ} \mathrm{C}$ the amount of material converted to volatiles increases from $0 \%$ to $5.0 \%$ [21]. The complete mass balances for softwood at $160{ }^{\circ} \mathrm{C}, 170^{\circ} \mathrm{C}$ and $180^{\circ} \mathrm{C}$ are illustrated in Table 4. Again the mass balances have been recreated with an initial starting material of $1000 \mathrm{~kg}$ for illustration purposes. Lignin content in the filtrate and residues was measured for the lower temperature conditions for both species and then assumed as the same for the other pretreatment conditions. This is not an unreasonable assumption since lignin is known to have a low solubility in acidic water.

\subsection{Process simulation}

A complete steady-state mass and energy balance process model for the integrated power plant and biorefinery facility was produced using WinGEMS V.5.3 [33,35]. This process simulation software was originally developed for use in the pulp and paper industry and therefore has specialty blocks and unit operations (solid/liquid handling washing and separation) particularly useful for application in pulp and paper and biorefinery facilities $[1,2]$. The simulation results were exported to a Microsoft Excel spreadsheet where it could be referenced for the economic evaluations.
Two main simulation models were built: (i) the base case in which only power was produced, and (ii) an integrated process in which power and alcohol are coproduced and the steam and electrical demands of the alcohol production facility are met by the power plant. The heating value of the feedstock both for the base case and alternative cases was estimated based on its composition (cellulose, hemicellulose, lignin, extractives and ash) following the methodology proposed by Jimenez and Gonzalez [36].

\subsubsection{Capital investment power plant}

Capital investment for biomass power plants vary greatly depending on the power generation capacity and process technology. Capital investment was estimated based on reported values found in the literature (based on dollars per kilowatt), with figures ranging from $\$ 1500 / \mathrm{kw}$ (year 2007) [37], \$3235/kw (year 2007) [38] and \$2500/kw (year 2009) [39]. Capital investment (CAPEX) for this project was estimated based on a production capacity of $72 \mathrm{MW}$ (plus an additional 5\% for CAPEX estimation). A CAPEX value of $\$ 2800$ (as of 2011) per kw of electricity was assumed. The CAPEX was inflated to year 2012, using the civil works construction cost index system of the US Army Corps of Engineers [40]. Total CAPEX (including $2 \%$ of indirect costs and $2 \%$ of contingency, as well as land) was estimated at $\$ 241.7$ million. The value of the land alone was estimated at $\$ 1.1$ million. A sensitivity analysis on the assumed value of CAPEX is presented in the Results and Discussion.

\subsubsection{Capital investment biorefinery}

Capital investment for the biorefinery plant includes: land purchase, land preparation, raw water treatment, waste water treatment, water hydrolysis extraction, enzymatic hydrolysis, membrane clean up, fermentation, beer column, rectification column, dehydration, and product storage and shipment. This yielded a $\$ 47$ million investment (as of 2012) for an ethanol production capacity of 7 million gallons ( 26.5 million liters), including $2 \%$ of indirect costs and $2 \%$ of contingency. The CAPEX of the biorefinery is recalculated for each feedstock and autohydrolysis treatment temperature, so the model sizes the CAPEX of the biorefinery depending on the total ethanol output. The estimated CAPEX for the biorefinery complex

Table 3

Extract and residues mass balance for hardwood after autohydrolysis.

\begin{tabular}{|c|c|c|c|c|c|c|c|c|}
\hline \multicolumn{9}{|c|}{ Mass balance hardwood } \\
\hline \multicolumn{3}{|c|}{ Starting material $1000 \mathrm{~kg}$ (O.D.) } & \multicolumn{2}{|c|}{$\begin{array}{l}\text { Temperature } 160^{\circ} \mathrm{C} \\
\text { Solids }\end{array}$} & \multicolumn{2}{|c|}{$\begin{array}{l}\text { Temperature } 170^{\circ} \mathrm{C} \\
\text { Solids }\end{array}$} & \multicolumn{2}{|c|}{$\begin{array}{l}\text { Temperature } 180^{\circ} \mathrm{C} \\
\text { Solids }\end{array}$} \\
\hline Component & $\%$ & $\mathrm{~kg}$ & Component & $\mathrm{kg}$ & Component & $\mathrm{kg}$ & Component & $\mathrm{kg}$ \\
\hline Lignin & 27 & 270.0 & Lignin & 264.6 & Lignin & 264.6 & Lignin & 264.6 \\
\hline Glucan & 46 & 460.0 & Glucan & 448.9 & Glucan & 449.0 & Glucan & 358.4 \\
\hline Hexan & 4 & 40.0 & Hexan & 0.0 & Hexan & 0.0 & Hexan & 0.0 \\
\hline Xylan & 19 & 190.0 & Xylan & 86.8 & Xylan & 24.2 & Xylan & 0.0 \\
\hline Extractives & 3 & 30.0 & Extractives & 0.0 & Extractives & 0.0 & Extractives & 0.0 \\
\hline Ash & 1 & 10.0 & Ash & 1.0 & Ash & 1.0 & Ash & 1.0 \\
\hline \multirow[t]{16}{*}{ Total } & & 1000.0 & Sub total & 801.3 & Sub total & 738.7 & Sub total & 624.0 \\
\hline & & & \multicolumn{2}{|l|}{ Dissolved solids } & \multicolumn{2}{|l|}{ Dissolved solids } & \multicolumn{2}{|l|}{ Dissolved solids } \\
\hline & & & Lignin & 5.4 & Lignin & 5.4 & Lignin & 5.4 \\
\hline & & & Glucan & 1.9 & Glucan & 4.3 & Glucan & 6.8 \\
\hline & & & Hexan & 6.1 & Hexan & 10.0 & Hexan & 9.0 \\
\hline & & & Xylan & 3.7 & Xylan & 19.0 & Xylan & 29.2 \\
\hline & & & Extractives & 3.0 & Extractives & 3.0 & Extractives & 3.0 \\
\hline & & & Ash & 9.0 & Ash & 9.0 & Ash & 9.0 \\
\hline & & & Oligomers & 82.6 & Oligomers & 90.5 & Oligomers & 65.6 \\
\hline & & & Acetic acid & 11.0 & Acetic acid & 24.0 & Acetic acid & 40.0 \\
\hline & & & Furfural & 1.0 & Furfural & 5.0 & Furfural & 13.0 \\
\hline & & & $\mathrm{HMF}$ & 1.0 & $\mathrm{HMF}$ & 1.0 & HMF & 2.0 \\
\hline & & & Formic acid & 11.0 & Formic acid & 16.0 & Formic acid & 18.0 \\
\hline & & & Volatiles & 63.0 & Volatiles & 74.0 & Volatiles & 175.0 \\
\hline & & & Sub total & 198.7 & Sub total & 261.3 & Sub total & 376.0 \\
\hline & & & Total material & 1000.0 & Total material & 1000.0 & Total material & 1000.0 \\
\hline
\end{tabular}


Table 4

Extract and residues yield for softwood after autohydrolysis.

\begin{tabular}{|c|c|c|c|c|c|c|c|c|}
\hline \multicolumn{9}{|c|}{ Mass Balance Softwood } \\
\hline \multicolumn{3}{|c|}{ Starting material $1000 \mathrm{~kg}$ (O.D.) } & \multicolumn{2}{|c|}{$\begin{array}{l}\text { Temperature } 160{ }^{\circ} \mathrm{C} \\
\text { Solids }\end{array}$} & \multicolumn{2}{|c|}{$\begin{array}{l}\text { Temperature } 170{ }^{\circ} \mathrm{C} \\
\text { Solids }\end{array}$} & \multicolumn{2}{|c|}{$\begin{array}{l}\text { Temperature } 180^{\circ} \mathrm{C} \\
\text { Solids }\end{array}$} \\
\hline Component & $\%$ & $\mathrm{~kg}$ & Component & $\mathrm{kg}$ & Component & $\mathrm{kg}$ & Component & $\mathrm{kg}$ \\
\hline Lignin & 29 & 290.0 & Lignin & 284.2 & Lignin & 284.2 & Lignin & 284.2 \\
\hline Glucan & 46 & 460.0 & Glucan & 448.7 & Glucan & 440.3 & Glucan & 434.1 \\
\hline Hexan & 14 & 140.0 & Hexan & 68.0 & Hexan & 39.8 & Hexan & 11.1 \\
\hline Xylan & 7 & 70.0 & Xylan & 40.0 & Xylan & 23.9 & Xylan & 16.8 \\
\hline Extractives & 3 & 30.0 & Extractives & 27.0 & Extractives & 7.0 & Extractives & 0.0 \\
\hline Ash & 1 & 10.0 & Ash & 1.0 & Ash & 1.0 & Ash & 1.0 \\
\hline \multirow[t]{16}{*}{ Total } & & 1000.0 & Sub total & 868.9 & Sub total & 796.2 & Sub total & 747.2 \\
\hline & & & \multicolumn{2}{|l|}{ Dissolved solids } & \multicolumn{2}{|l|}{ Dissolved solids } & \multicolumn{2}{|l|}{ Dissolved solids } \\
\hline & & & Lignin & 5.8 & Lignin & 5.8 & Lignin & 5.8 \\
\hline & & & Glucan & 1.9 & Glucan & 9.8 & Glucan & 19.2 \\
\hline & & & Hexan & 13.6 & Hexan & 20.1 & Hexan & 25.2 \\
\hline & & & Xylan & 4.6 & Xylan & 17.0 & Xylan & 20.7 \\
\hline & & & Extractives & 3.0 & Extractives & 3.0 & Extractives & 3.0 \\
\hline & & & Ash & 9.0 & Ash & 9.0 & Ash & 9.0 \\
\hline & & & Oligomers & 66.6 & Oligomers & 87.7 & Oligomers & 72.9 \\
\hline & & & Acetic acid & 8.6 & Acetic acid & 14.0 & Acetic acid & 23.0 \\
\hline & & & Furfural & 0.9 & Furfural & 2.0 & Furfural & 5.0 \\
\hline & & & $\mathrm{HMF}$ & 0.9 & HMF & 1.5 & $\mathrm{HMF}$ & 4.0 \\
\hline & & & Formic acid & 16.2 & Formic acid & 14.0 & Formic acid & 15.0 \\
\hline & & & Volatiles & & Volatiles & 20.0 & Volatiles & 50.0 \\
\hline & & & Sub total & 131.1 & Sub total & 203.8 & Sub total & 252.8 \\
\hline & & & Total material & 1000.0 & Total material & 1000.0 & Total material & 1000.0 \\
\hline
\end{tabular}

producing 7 million gallons of ethanol per year (26.5 million liters per year) is presented in Table 5. CAPEX for the biorefinery was built based on previous techno-economic reports and by consulting experts $[8,34,41,42]$. CAPEX estimation was based on green tons of feedstock for autohydrolysis and enzymatic hydrolysis, autohydrolysis filtrate flow for membrane clean-up, and beer flow for fermentation, beer column, rectification column and dehydration.

\subsection{Economic analysis}

The major cost drivers and assumptions are listed for the economic analysis of the base and alternative case in Tables 6 and 7.

For all cases, the evaluation horizon has been set for 15 years. A terminal value in year 15 of seven times year 15 EBITDA (Earnings Before Interest, Taxes, Depreciation and Amortization) was assumed. The discount rate used for the biomass to electricity production case (Table 7) was 6\%; this was based on the value of the weighted average capital costs (WACC) for electric utility companies on the east coast of the US [43] and the market return of "risk free" portfolios (based on the return of US treasury bills) [44]. In the case of ethanol production, a discount rate of $12 \%$ has been as-

Table 5

Capital investment for an ethanol biorefinery producing 7 million gallons per year (Softwood $170^{\circ} \mathrm{C}$ ). Source: [8,34,41,42].

\begin{tabular}{lll}
\hline Description & Scale factor & Green field US\$ \\
\hline Land purchase & 0.9 & 36,953 \\
Land preparation & 0.9 & $1,011,525$ \\
Raw water treatment & 0.7 & 433,417 \\
Waste water treatment & 0.7 & 650,126 \\
Water hydrolysis & 0.7 & $12,707,471$ \\
Enzymatic hydrolysis & 0.7 & $11,628,920$ \\
Membrane clean up & 0.7 & $8,895,230$ \\
Fermentation & 0.8 & $5,630,195$ \\
Beer column & 0.8 & $1,278,155$ \\
Rectification column & 0.8 & $1,186,793$ \\
Dehydration & 0.7 & $1,293,582$ \\
Product storage and shipment & 0.6 & $1,658,609$ \\
\hline
\end{tabular}

Table 6

Operative and financial assumption for power plant (base case).

\begin{tabular}{ll}
\hline Description & Value \\
\hline Feedstock supply, BDT/year & 500,000 \\
Startup year & 2013 \\
Terminal year & 2027 \\
\% of CAPEX spending in year-2 & $30 \%$ \\
\% of CAPEX spending in year-1 & $50 \%$ \\
\% of Spending in year 0 & $20 \%$ \\
\% of Nominal capacity, project year 1 & $80 \%$ \\
$\%$ of Nominal capacity, project year 2 & $90 \%$ \\
Working capital per cent of direct cost & $10 \%$ \\
Years depreciation schedule & 10 \\
Tax rate, with tax loss carryforward & $35 \%$ \\
Discount rate & $6 \%$ \\
Terminal value, year 15 EBITDA multiple & 7 \\
Hours per year & 8400 \\
Biomass Cost, \$ per dry Ton & 38.2 \\
Moisture content\% & $40 \%$ \\
Hourly and administrative staff (non-maintenance) & 16 \\
Salaried staff & 4 \\
Maintenance expense, including labor, \% of replacement asset & $1.0 \%$ \\
$\quad$ value & \\
Capital reinvestment, \% of replacement asset value & $0.5 \%$ \\
Other fixed costs, \% of sales & $1.0 \%$ \\
Sales and other overhead, \% of sales & $1.0 \%$ \\
\hline
\end{tabular}

sumed for this project because this is a technology yet to be demonstrated on commercial scale and this discount rate is consistent with other studies $[1,2,45,46]$. All costs have been scaled up to year 2012. The analysis has been constructed to estimate the minimum power or ethanol selling price to achieve a specific rate of return (or discount rate) rather than assuming a price for ethanol (or power). A discussion of how these minimum selling prices compare to current prices found in the market is presented in Section 3.9 of this manuscript.

\section{Results and discussions}

In order to understand the tradeoff between producing power and cellulosic ethanol in an integrated process, it is important to 
Table 7

Operative and financial assumption for the biorefinery.

\begin{tabular}{|c|c|c|c|c|c|}
\hline Description & Value & $\mathrm{S}$ & Description & Value & $\mathrm{S}$ \\
\hline Additional wood & Backcalculated & & Biomass cost, $\$$ per dry ton & 38.2 & $\mathrm{E}$ \\
\hline Startup year & 2013 & A & Moisture content, \% of green ton & $40 \%$ & $\mathrm{E}$ \\
\hline Terminal year & 2027 & A & Enzyme cost, \$ per gallon ethanol & 0.20 & A \\
\hline$\%$ of Spending in year-2 & $30 \%$ & $\mathrm{E}$ & Yeast Cost, $\$$ per Gallon Ethanol & 0.07 & 1 \\
\hline$\%$ of Spending in year- 1 & $50 \%$ & $\mathrm{E}$ & Hourly and administrative staff (non-maintenance) & 21 & $\mathrm{E}$ \\
\hline$\%$ of Spending in year 0 & $20 \%$ & $\mathrm{E}$ & salaried staff & 4 & $\mathrm{E}$ \\
\hline$\%$ of Nominal capacity, project year 1 & $80 \%$ & $\mathrm{E}$ & Maintenance expense, including labor, \% of replacement asset value & $1.0 \%$ & $\mathrm{E}$ \\
\hline$\%$ of Nominal capacity, project year 2 & $90 \%$ & $\mathrm{E}$ & Capital reinvestment, \% of replacement asset value & $0.5 \%$ & $\mathrm{E}$ \\
\hline Excess material use in project year 1 & $30 \%$ & $\mathrm{E}$ & Other fixed costs, \% of sales & $1.0 \%$ & $\mathrm{E}$ \\
\hline Working capital per cent of direct cost & $10 \%$ & $\mathrm{E}$ & Sales and other overhead, \% of sales & $1.0 \%$ & $\mathrm{E}$ \\
\hline Years depreciation schedule & 10 & $\mathrm{E}$ & Hydrolysis residence time & $1 \mathrm{~h}$ & 2 \\
\hline Tax rate, with tax loss carryforward & $35 \%$ & $\mathrm{E}$ & Sugar loss during washing/screw press & $9.1 \%$ & $\mathrm{E}$ \\
\hline Discount rate & $12 \%$ & A & Filter efficiency & $90 \%$ & A \\
\hline Terminal value, year 15 EBITDA multiple & 7 & A & Fermentation efficiency C5 & $85 \%$ & A \\
\hline Hours per year & 8400 & A & Fermentation efficiency C6 & $95 \%$ & A \\
\hline
\end{tabular}

$\mathrm{S}=$ Source; $\mathrm{A}=$ Assumption; $\mathrm{E}=$ Expert consultation $[41,42] ; 1=[1] ; 2=[21]$.

review some aspects of stand-alone biomass power production costs, profitability as well as effect of feedstock and moisture content.

\subsection{Feedstock cost}

The average feedstock delivered cost was estimated at $\$ 38.2$ per dry short ton ( $\$ 42.1$ per dry metric tonne) for both softwood and hardwood. The estimation of the feedstock delivered cost was based on the cost per green ton [free on board (FOB)] and transportation cost (for an average transportation distance of 40 miles and transportation fee at $\$ 0.13$ per green ton per loaded mile) taken from the last eight quarterly publications of Timber Mart-South [47]. This average delivered cost was similar to the price paid for hog fuel in several locations in the Southern US as of the third quarter of 2011 [32]. Though an average price of $\$ 38.2$ per dry short ton (BDT) was used, there is an expected distribution of feedstock cost following a Lognorm distribution (Fig. 2). The distribution model fit was done using the distribution fit function of the @Risk software [48]. Note from the top of the graph (Fig. 2) that
$70 \%$ of the values exist in an interval between $\$ 20$ and $\$ 40$ per BDT delivered.

\subsection{Power generation}

Power generation varies depending on the chemical composition and moisture content of the feedstock. In our process simulation, the same annual input of hardwood or softwood at the same moisture content produced slightly different amounts of electricity. An annual supply of 500,000 BDT of softwood produced $\sim 73.3 \mathrm{MW}$, while the same quantity of hardwood produced $\sim 72.8 \mathrm{MW}$, with an efficiency of $22.8 \%$ and $22.7 \%$ respectively (based on low heating values). These values are consistent with other publications $[37,49,50]$.

\subsection{Power generation costs}

Power generation cost using an annual input of 500,000 BDT of softwood (40\% moisture content) is presented in Fig. 3 (bars show absolute values while pie chart shows percentage values). Major

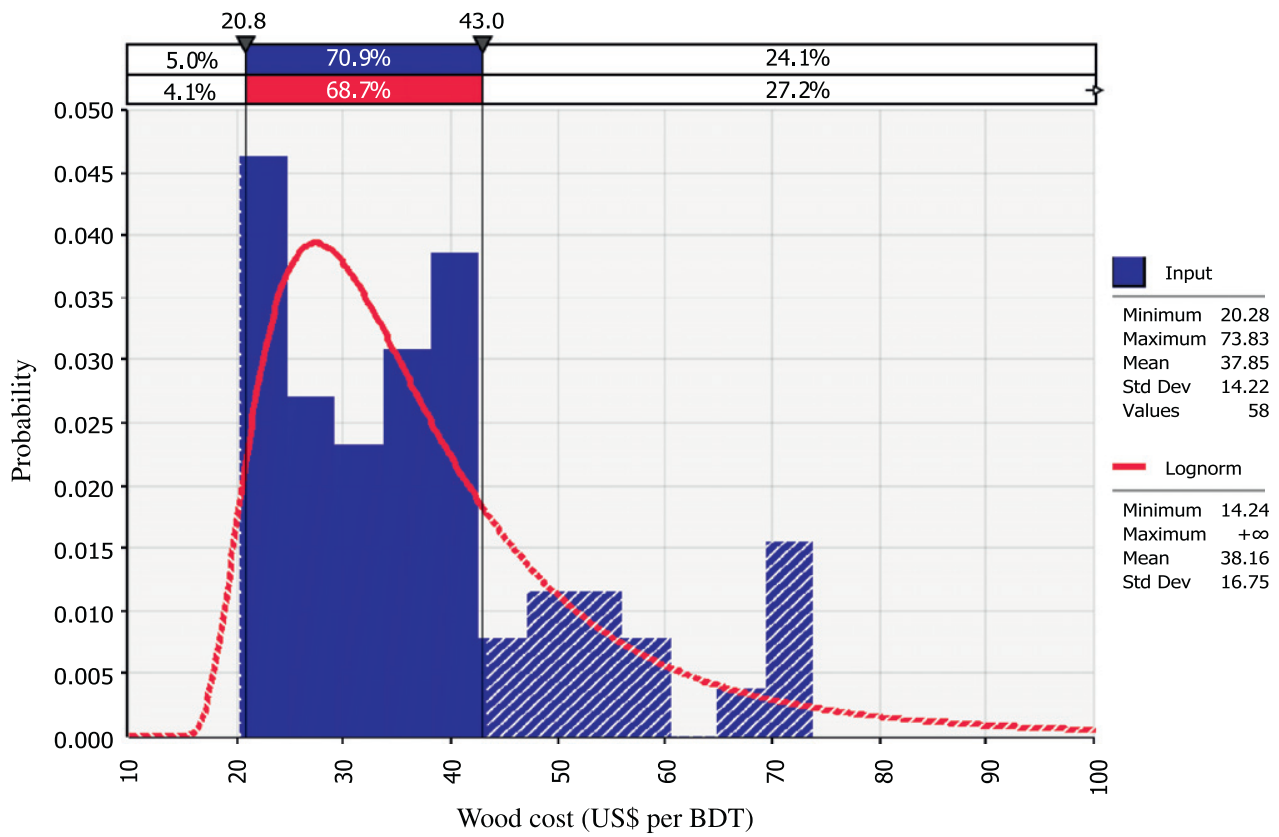

Fig. 2. Distribution of feedstock delivered cost in US\$ dollars per BDT, $(1$ dry metric tonne $=1.1023$ BDT $)$. 


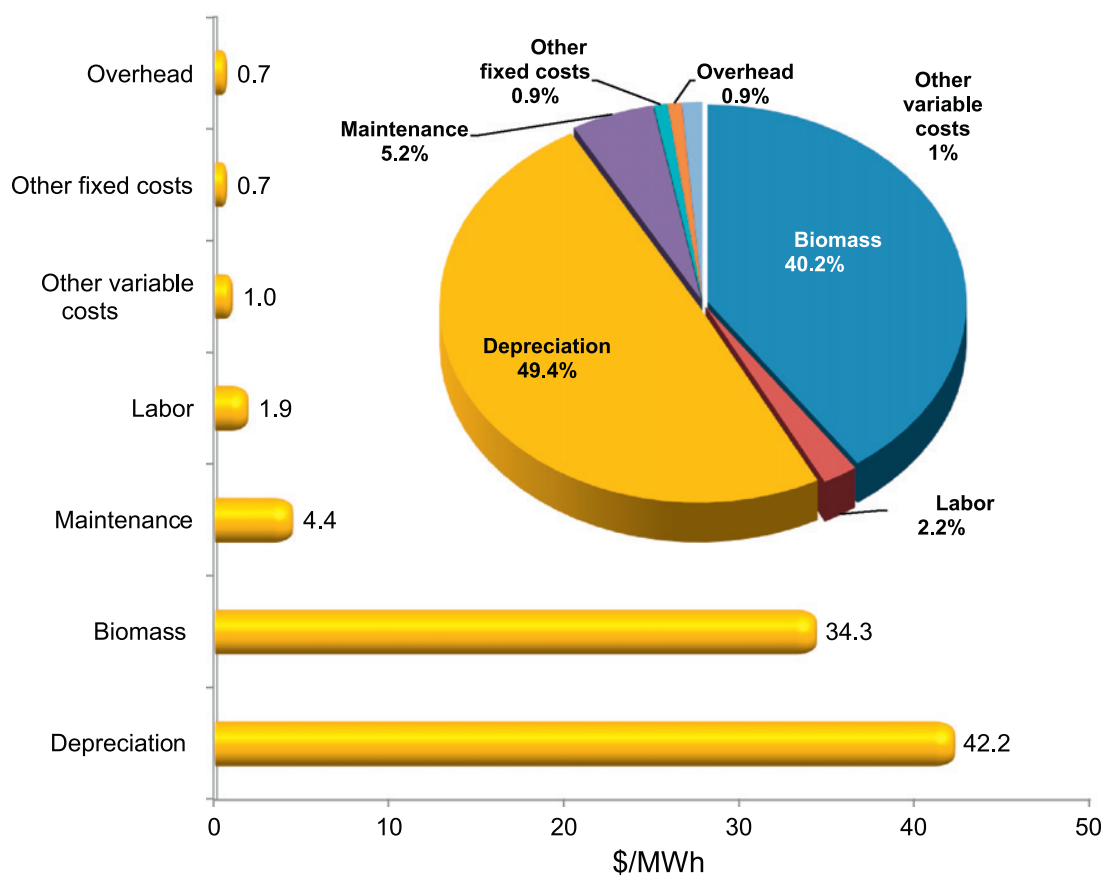

Fig. 3. Power generation costs using softwood feedstock.

cost drivers are biomass and depreciation (\$34.3 and $\$ 42.2$ per MWh, respectively) adding up to $\sim 88 \%$ of total costs. A similar cost structure was observed for hardwood (not shown here). The relative importance of feedstock cost in the total power generation cost is one of the major limitations to increase the size of biomass power plants. Higher tonnage input of biomass would require longer feedstock hauling distances and increased delivered costs. One major handicap of biomass power compared to coal power is the cost of delivered raw material. Coal can be delivered at a cost relatively insensitive to the quantity demanded while biomass becomes increasingly more expensive as more biomass at a single location is demanded. In this analysis the feedstock cost was held constant with no additional cost for higher volumes supplied to the market.

\subsection{Minimum selling revenue required}

The minimum selling revenue analysis estimates the required minimum wholesale price of electricity to achieve a specific internal rate of return. The minimum revenue of electricity required in order to achieve an internal rate of return of $6 \%, 8 \%, 10 \%$ and $12 \%$, using softwood or hardwood, are shown in Fig. 4. In general, minimum revenue required values are lower in softwood because softwood has a slightly higher heating value resulting in more power

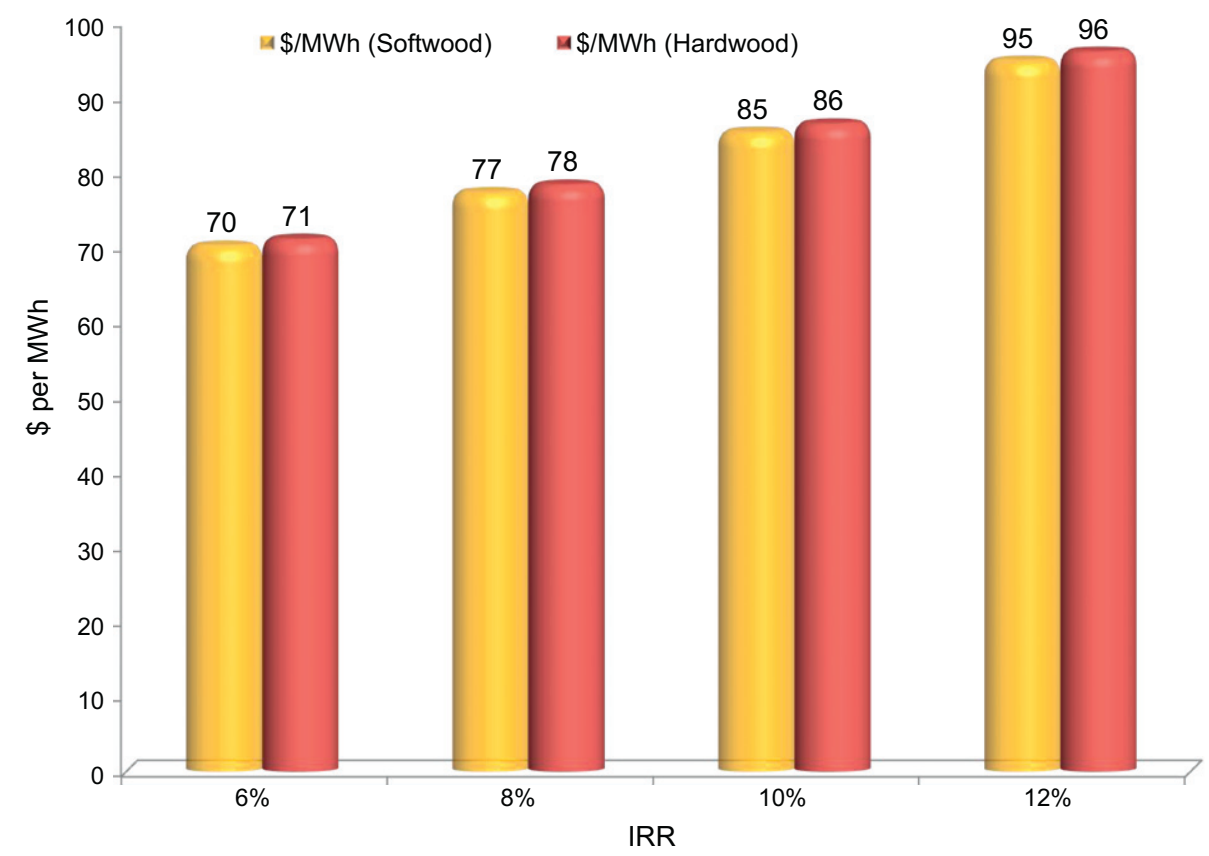

Fig. 4. Minimum revenue required per MWh of electricity at different values of internal rate of return (IRR). 
generation per unit biomass. Minimum revenue required for softwood ranges from $\$ 70$ per MWh (at 6\% IRR) to $\$ 95$ per MWh (at $12 \%$ IRR), while minimum electricity revenue for hardwood ranges from $\$ 71$ per MWh (at 6\% IRR) to $\$ 96$ per MWh (at 12\% IRR).

\subsection{Moisture content effect on power generation and minimum whole selling price}

One of the major factors influencing biomass to power generation efficiency is the moisture content of the feedstock. It is expected that feedstock with lower moisture content will produce higher energy output compared to feedstock with higher moisture content. Fig. 5 shows the effect of moisture content on electricity generation and minimum electricity revenue required (using hardwood as feedstock) to achieve a specific rate of return of $6 \%$ and $12 \%$. For this sensitivity analysis, a range of $20-55 \%$ moisture content is presented. As moisture content increases, electricity generation (MW) decreases. Feedstock at 20\% moisture content would produce $\sim 79 \mathrm{MW}$, whereas the outcome for feedstock at $55 \%$ moisture would be $66.6 \mathrm{MW}$. When moisture content is lower and electricity generation is higher ( $20 \%$ moisture content), the minimum electricity whole sale revenue required is $\$ 65$ and $\$ 88$ per MWh to achieve a $6 \%$ and $12 \%$ IRR respectively. When moisture content increases to $35 \%$, the minimum whole sale electricity revenue required rises to $\$ 78$ per MWh (6\% IRR).

\subsection{Ethanol production cost}

Ethanol production costs, minimum ethanol revenue and other economic indicators are analyzed for each of the alternative cases (as listed in Table 2). The ethanol production costs for softwood at $170{ }^{\circ} \mathrm{C}$ are shown in Fig. 6 . The method for distributing production cost for ethanol, specifically for feedstock and energy, is as follows: the model estimated the amount of feedstock required to produce $\sim 72 \mathrm{MW}$, all additional wood (additional wood relative to the base case input of 500,000 BDT per year) was charged to the cost center of ethanol feedstock. Energy cost was estimated from the energy used (by the biorefinery facility), and it was considered as a cost to the biorefinery assuming a cost rate of $\$ 64$ per MWh (power and process steam were calculated using the engineering software WinGEMS). In other words, the electrical demand of the ethanol production equipment is satisfied by the electricity produced by the biomass power facility and sold at whole sale price. In Fig. 6 it can be observed that feedstock ( $35 \%$ of production costs), depreciation (26\%) and energy (14\%) are the major cost drivers accounting for $\sim 75 \%$ of total production costs.

The main findings of the economic analysis focus on the interaction between the different extraction conditions, feedstocks and the economic indicators for ethanol production. Fig. 7 shows additional wood input, ethanol production and total wood sent to the autohydrolysis reactor for sugar extraction (87\% of total wood input). The highest ethanol production scenario is observed for softwood at $170{ }^{\circ} \mathrm{C}$ (26.6 million liters per year). Both softwood and hardwood had the highest ethanol output at $170^{\circ} \mathrm{C}$. Lower additional wood input was determined for softwood because the amount of material extracted to produce ethanol is lower at a given temperature compared to hardwood. For the two feedstocks, the additional wood input increases at higher temperature (more material extracted during autohydrolysis) [21]. However, higher extraction rates do not necessarily translate into greater ethanol production because of yield loss to sugar degradation products at higher temperatures. Additional wood input ranged from 118 thousand BDT per year (softwood $160^{\circ} \mathrm{C}$ ) to 249 thousand BDT per year (hardwood $180^{\circ} \mathrm{C}$ ). Ethanol yields (wood sent to hydrolysis) for hardwood at process conditions of 160,170 and $180^{\circ} \mathrm{C}$ were 37.2, 41.6 and 31.61 of ethanol per BDT of feedstock, respectively. Ethanol yield for softwood at process conditions of 160, 170 and $180^{\circ} \mathrm{C}$ were $32.9,45.6$ and 39.91 per BDT respectively.

\subsection{Minimum ethanol revenue required, cash cost and production cost}

Fig. 8 shows production costs, cash cost and minimum ethanol revenue required (estimated to achieve 12\% IRR). The lowest production costs, cash costs and minimum ethanol revenue required are observed at $170{ }^{\circ} \mathrm{C}$ for both feedstocks. Overall lower values are observed for softwood, explained by less sugar degradation to

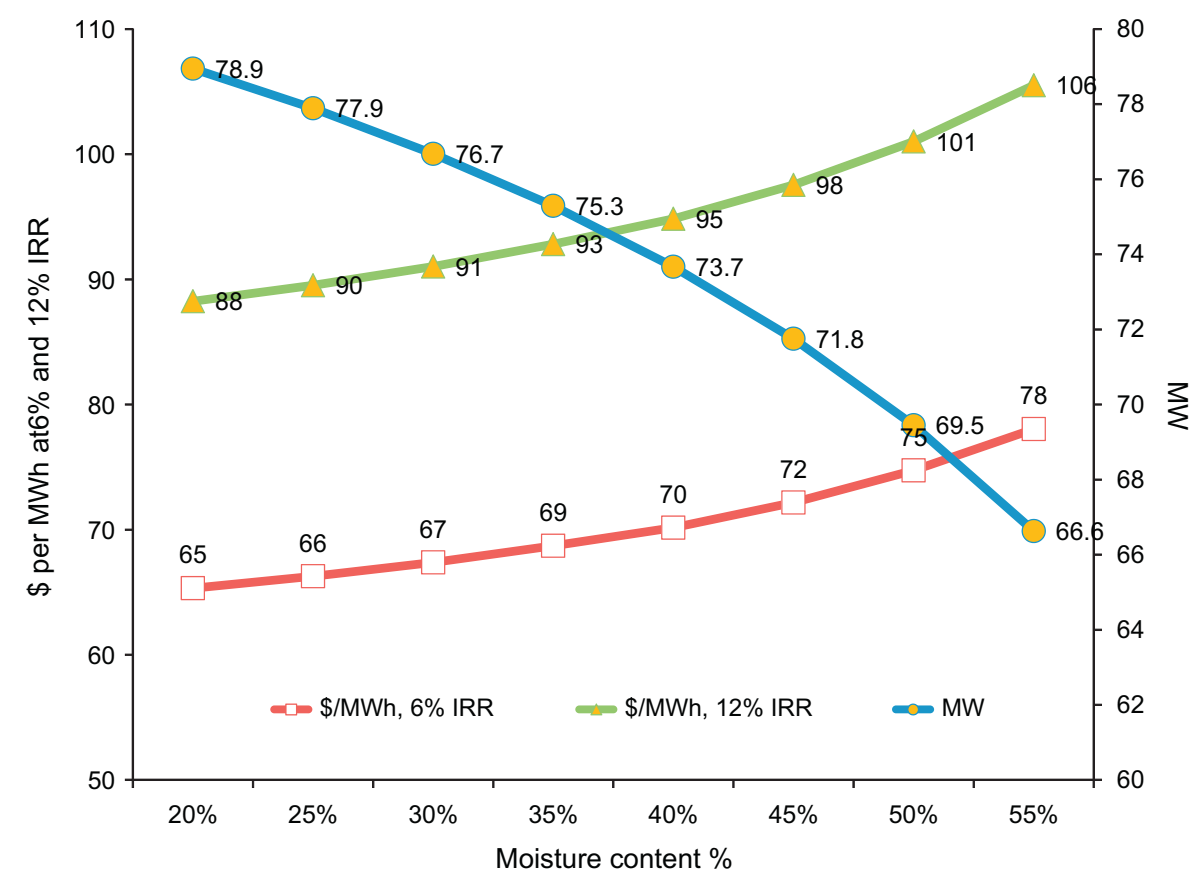

Fig. 5. Effect of moisture content on electricity production for 500,000 BDT and minimum revenue required (to achieve $6 \%$ and $12 \%$ IRR). 


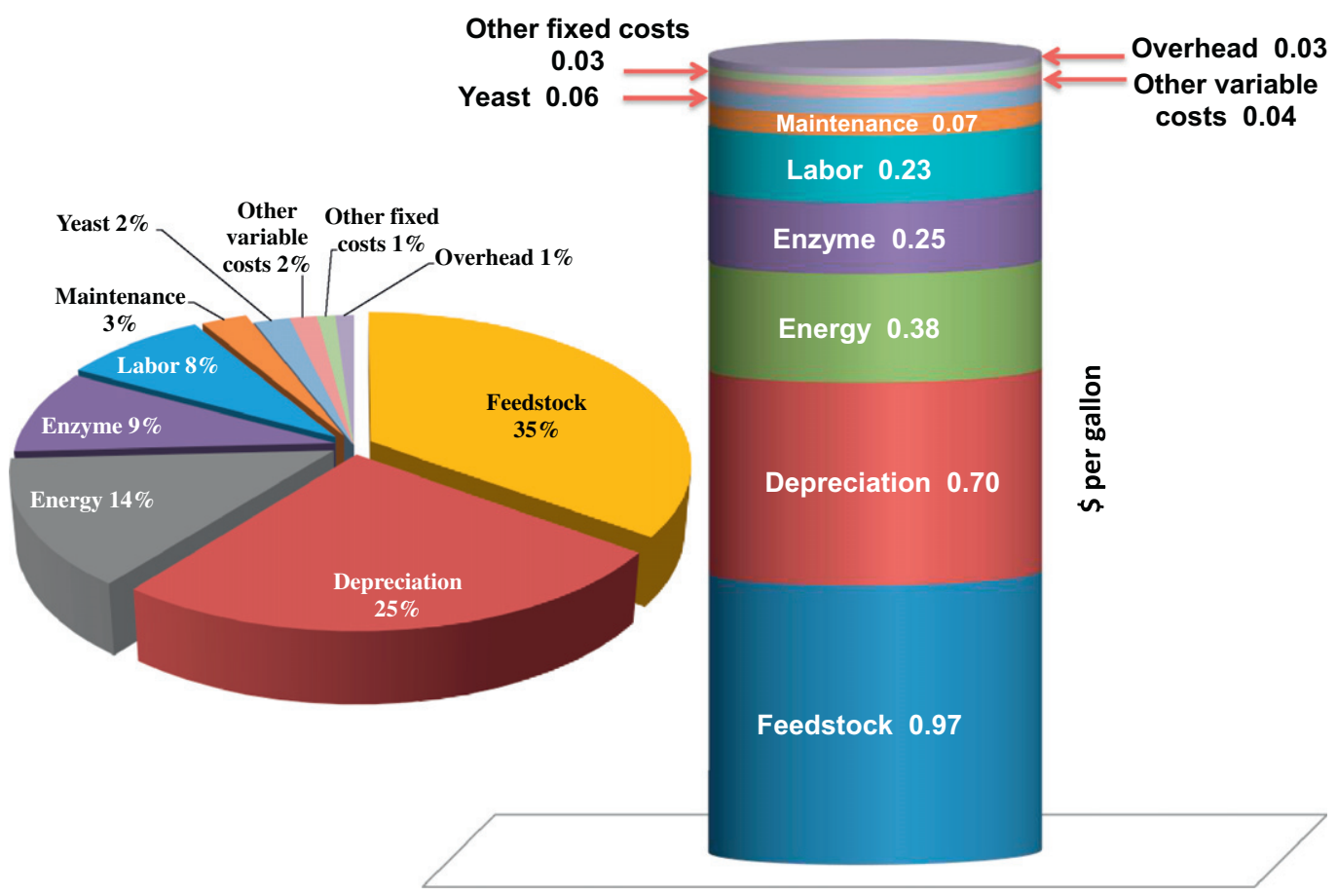

Fig. 6. Ethanol production costs per gallon of ethanol (Softwood $\left.170{ }^{\circ} \mathrm{C}\right), 1$ gallon $=3.785 \mathrm{l}$.

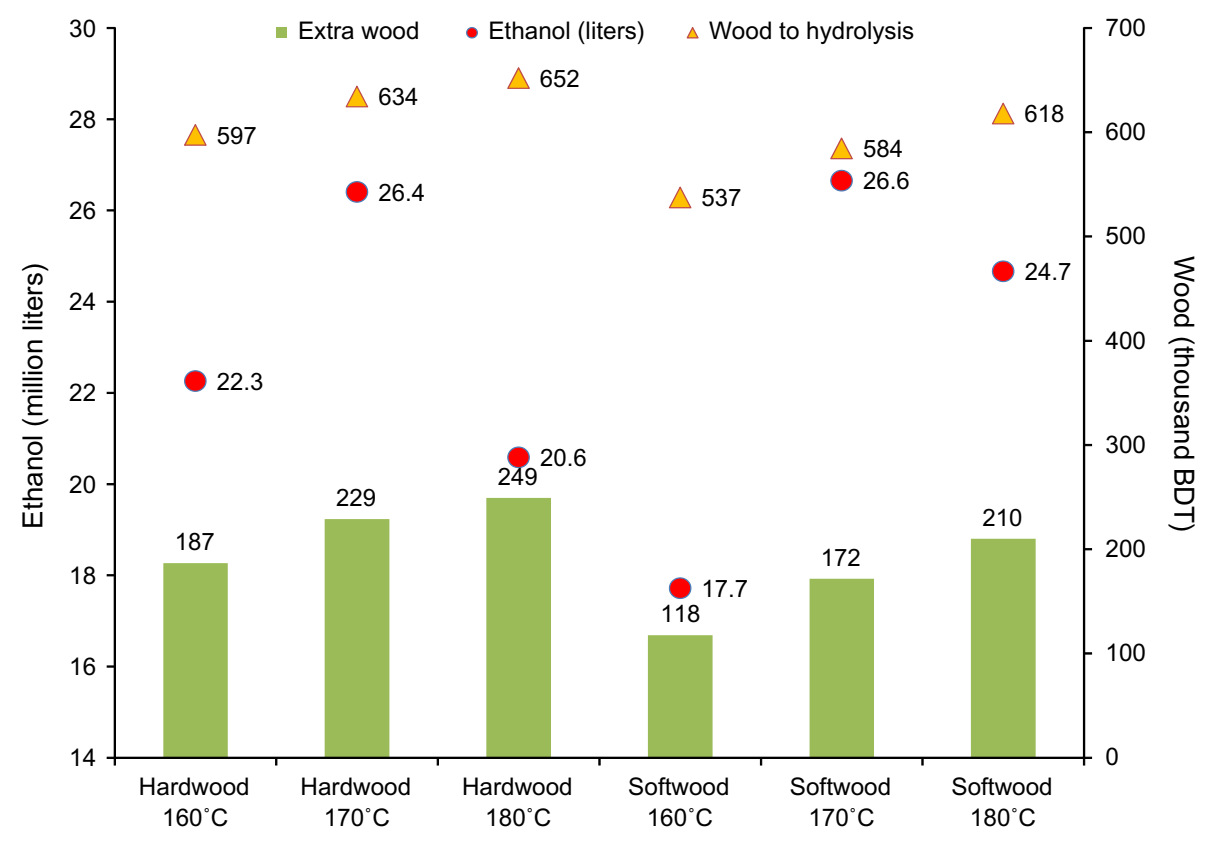

Fig. 7. Ethanol production, wood to hydrolysis and additional wood purchased for each autohydrolysis condition.

unwanted components, producing more ethanol output and requiring less additional wood input. Minimum ethanol revenue required (MER) ranged from $\sim \$ 0.74-1.05$ per liter of ethanol (FOB) at the plant for the cases considered.

\subsection{Return on investment and payback}

Returns on investment, payback and minimum ethanol revenue were estimated for all cases. Return on investment (ROI) is a popular financial indicator calculated as the ratio between the after tax income with respect to the assets used to generate such revenue in the project. Across the fifteen year evaluation horizon, both feedstocks at $170{ }^{\circ} \mathrm{C}$ present the higher ROI with values of $\sim 7 \%$ for year nine (Payback period). Lower ROI was observed for both feedstocks at the highest temperature $\left(180^{\circ} \mathrm{C}\right)$, with values of $\sim 6 \%$ for year nine. Payback is the time required to offset the initial investments. In other words, it is the time required such that the accumulated free cash flow at historical values becomes positive. As expected the lower payback periods are observed in those conditions with lower production costs, cash costs and minimum ethanol revenues, with payback around 9 years (softwood $170^{\circ} \mathrm{C}$ followed by hardwood $170^{\circ} \mathrm{C}$ ). 


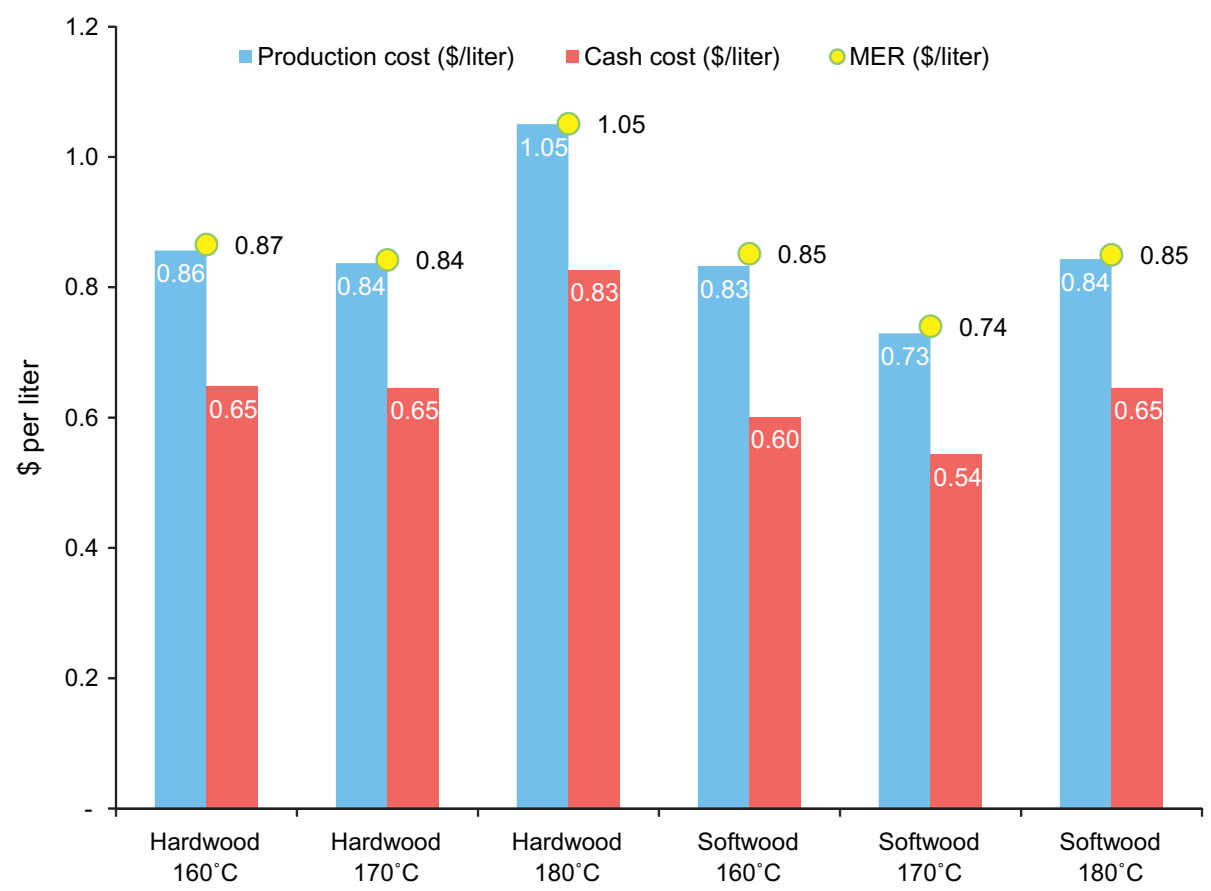

Fig. 8. Minimum ethanol revenue required (12\% IRR), cash cost and production cost for each autohydrolysis condition.

\subsection{By-products}

As discussed previously, degradation of sugars occurs at elevated temperatures in the presence of acid leading to the formation of byproducts of which furfural, hydroxymethylfurfural, acetic acid, and formic acid are the most abundant. Table 8 illustrates the amount of these four components recovered after separation from the hydrolyzate stream (using membranes). More byproducts are produced from hardwoods relative to softwoods at a given temperature. More byproducts are produced from a given feedstock as the autohydrolysis temperature increases. No revenue has been considered from these byproducts but they could be purified with additional equipment and then sold.

\subsection{Sensitivity analysis}

A sensitivity analysis describes how the system variables impact the economic forecast of a project. An analysis of this kind also helps to guide future development to mitigate risk. The response variable chosen to understand sensitivity impact was the minimum ethanol revenue required (estimated to achieve a $12 \%$ IRR). The sensitivity analysis was built with a variation of $\pm 25 \%$ of the central values for CAPEX, ethanol yield, biomass cost and enzyme cost (Fig. 9).

The MER is most sensitive to ethanol yield, followed by biomass cost and CAPEX. In the most favorable case, a 25\% increase in yield may drop the MER to \$0.64 per liter. Reducing feedstock cost and enzyme cost individually by $25 \%$ can decrease the MER to $\sim \$ 0.67$ per liter of ethanol.
Ethanol market prices have varied considerably in the past decade. A key consideration when conducting simulations in which prices are allowed to randomly vary requires an understanding of the shape of the probability distribution of these prices. The shape of the probability distribution of ethanol market price in the period between January 2002 and July 2011 was estimated using the distribution fit function of @Risk software, which determines the parameters of the probability distribution that is most consistent with observed data. The distribution indicated that approximately $20 \%$ of the ethanol selling prices fall in the range of $\$ 0.64+$ liter. Fig. 10 presents the historic selling price for ethanol and regular gasoline in Omaha, Nebraska, US [51]. Although the selling price for ethanol has increased drastically over the past decade, a reasonable estimate of future ethanol selling price is likely around $\$ 0.60-\$ 0.70 / 1$.

If a future ethanol selling price of $\$ 0.65 / 1$ is assumed, the technology outlined herein to produce bioethanol via autohydrolysis of wood would have to have a $25 \%$ higher yield to achieve a $12 \%$ IRR (Fig. 9). This technology is relatively insensitive to enzyme cost but a reduction of CAPEX and biomass costs are other variables in addition to yield that have potential to improve the financial prospects of a VPC project. Note that the calculated minimum ethanol revenue required calculations ranged from $\$ 0.74$ to $\$ 1.05$ per liter of ethanol for the six cases, indicating that it is not economically feasible under current ethanol prices to pursue VPC.

In order to provide a measure of the probability of investment failure or success, the probability distribution of the NPV is presented as a function of all operational data and the probability distribution of enzyme cost, feedstock cost, CAPEX, and yield. All

Table 8

Formation of acetic acid, formic acid, furfural and hydroxymethylfurfural for each autohydrolysis condition.

\begin{tabular}{|c|c|c|c|c|c|c|}
\hline Byproducts (ton/year) & Hardwood $160^{\circ} \mathrm{C}$ & Hardwood $170^{\circ} \mathrm{C}$ & Hardwood $180^{\circ} \mathrm{C}$ & Softwood $160^{\circ} \mathrm{C}$ & Softwood $170^{\circ} \mathrm{C}$ & Softwood $180^{\circ} \mathrm{C}$ \\
\hline Acetic acid & 4486 & 10,399 & 17,827 & 3132 & 5585 & 9708 \\
\hline Formic acid & 5098 & 7880 & 9117 & 6723 & 6347 & 7196 \\
\hline Furfural & 463 & 2461 & 6585 & 395 & 906 & 2397 \\
\hline Hydroxymethylfurfural & 463 & 492 & 1012 & 395 & 682 & 1918 \\
\hline
\end{tabular}




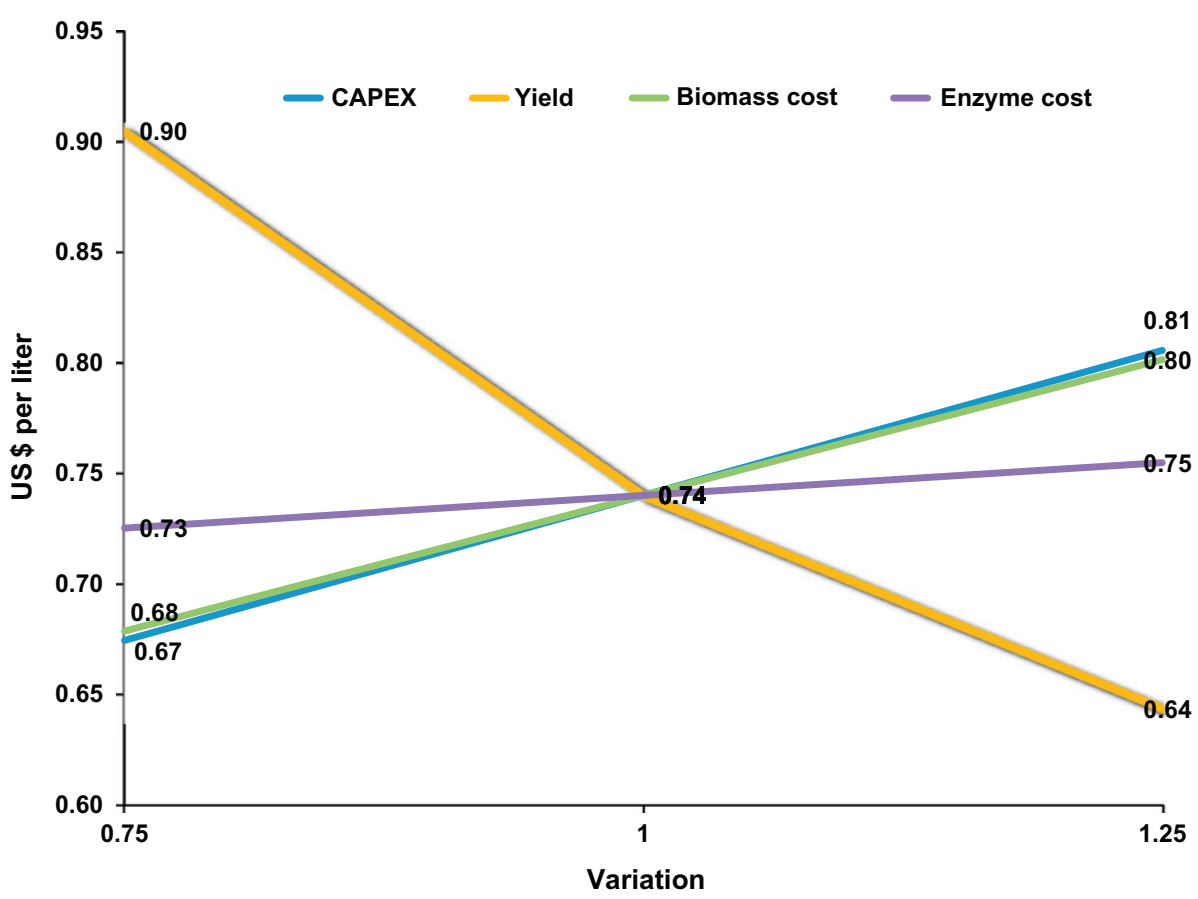

Fig. 9. Sensitivity of minimum ethanol revenue required ( $12 \%$ IRR) with variation of $\pm 25 \%$ for CAPEX, yield, biomass cost and enzyme cost (Case: Softwood $170{ }^{\circ} \mathrm{C}$ ).

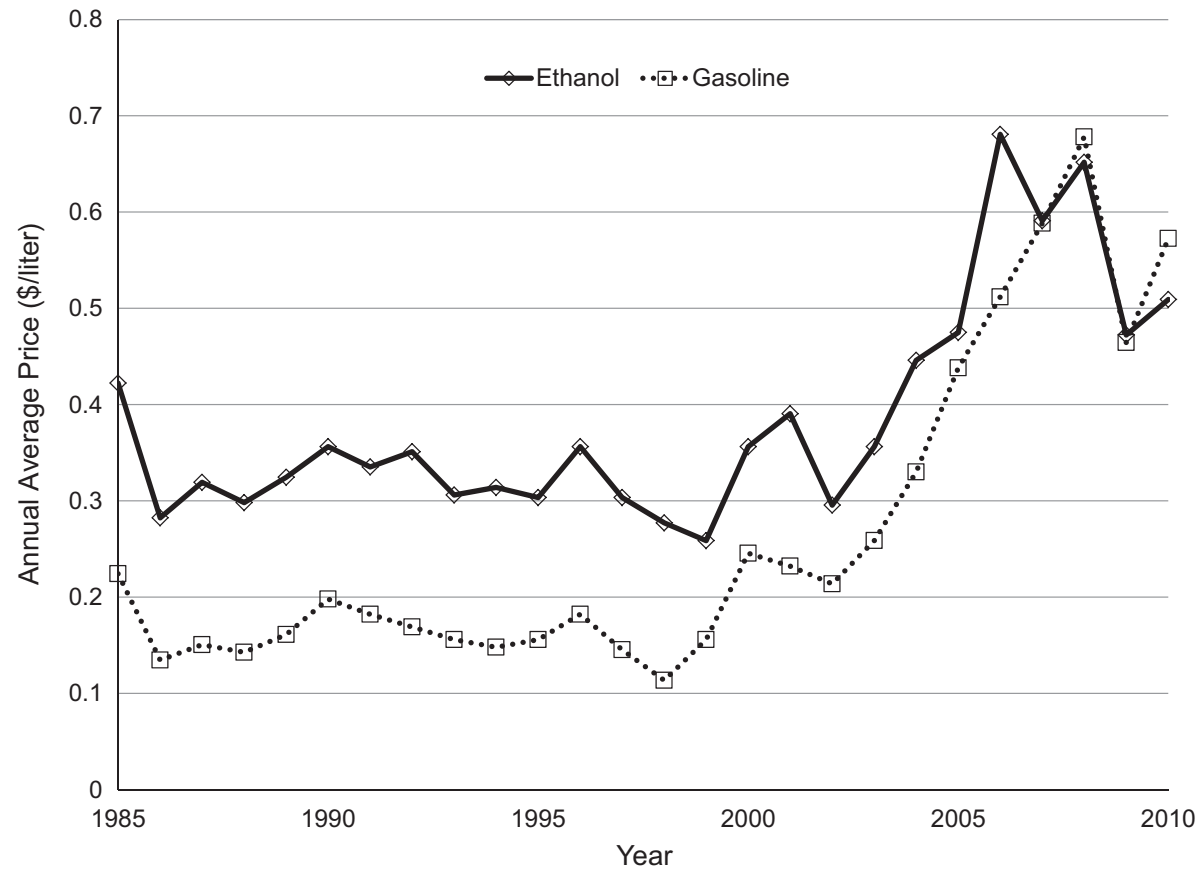

Fig. 10. Historic ethanol and regular gasoline price FOB Omaha, Nebraska, US.

distributions were fit using @Risk software [48]. The probability distribution of the feedstock cost is the same as presented in Fig. 2. The probability distribution of enzyme cost (\$ per liter), CAPEX, and ethanol output (in liters) were modeled following rectangular distributions based on the assumption of $\pm 25 \%$ with respect to the central assumption listed in the methodology section. These potential sources of variations affect the distribution of the NPV values of the project (Fig. 11). The simulation was performed with 500 iterations using the simulation module of @Risk. For this evaluation, instead of evaluating the minimum revenue required per liter of ethanol, a wholesale selling price of $\$ 0.65$ per liter of ethanol was used along with a discount rate of $12 \%$. From the distribution of the NPV listed in Fig. 11, it was possible to assign a percentage of failure or success for the project. It can be observed that only $26.6 \%$ of the distribution of the NPV is above zero, which means that there is a probability of $26.6 \%$ to achieving an internal rate of return equal or higher than $12 \%$. Previous studies addressing the co-production of power and ethanol have concluded that mature technologies could be profitable in the long term $[52,53]$. One main influence that may lead to improved economics of the 


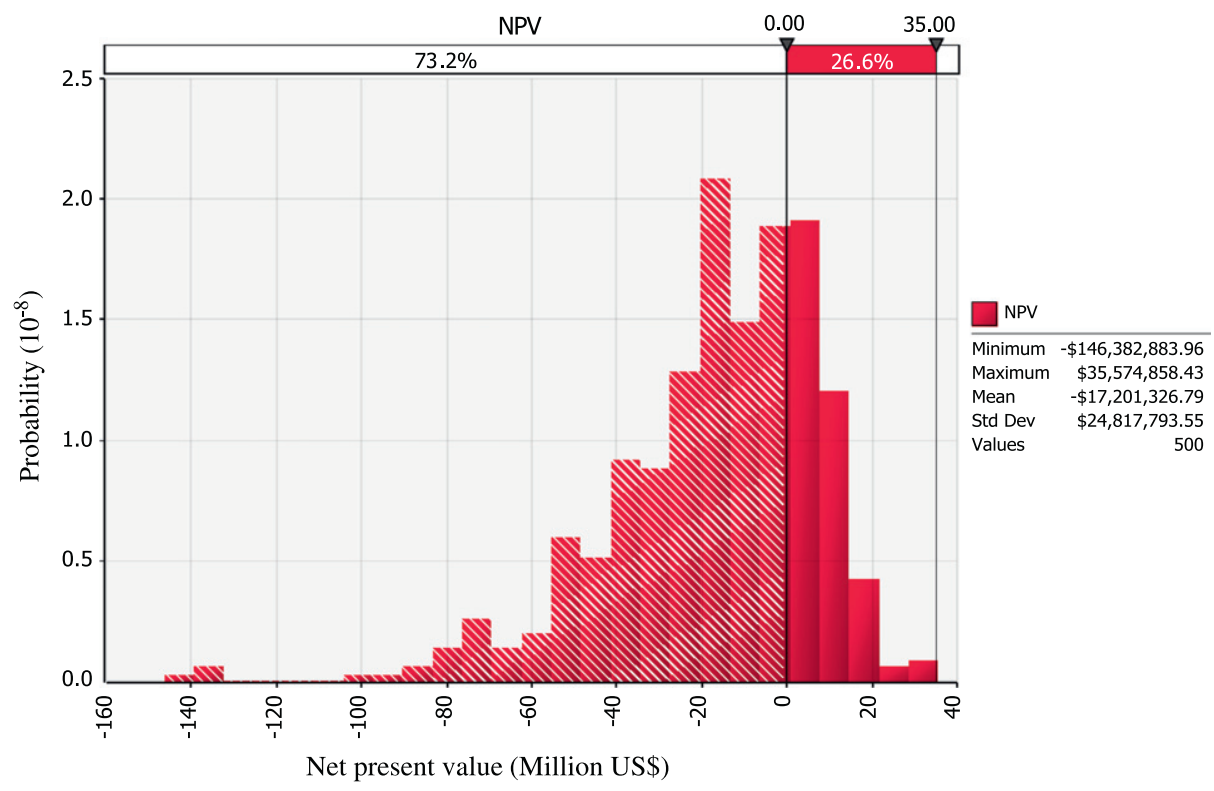

Fig. 11. Probability distribution of the NPV value of the project (discount rate $12 \%$ ).

biorefinery is increased plant capacity [52], although higher feedstock costs will then become a major limitation [9].

\section{Conclusions}

The concept of VPC (value prior to combustion) is technically feasible but the minimum ethanol revenues required to produce a $12 \%$ internal rate of return are high enough to discourage investors if future prices are distributed similarly to the last decade's historical prices. Under the current assumptions and scenarios evaluated, the lowest minimum ethanol revenue required to achieve a $12 \%$ IRR ( $\$ 0.74 / 1)$ occurs for softwood at an extraction temperature of $170{ }^{\circ} \mathrm{C}$. This revenue requirement is higher than the assumed future ethanol selling price of $\$ 0.65 / 1$. The base case analysis showed that electrical power from biomass must sell for $\$ 70-\$ 96 /$ MWh to achieve internal rates of return of $6-12 \%$. The financial performance of this autohydrolysis technology appears to be most sensitive to ethanol yield followed by CAPEX and biomass cost. Biomass cost, much like ethanol selling price, is subject to rules of the open market. Therefore, it is suggested that focus be placed on improving yield and reducing CAPEX before this technology can be applied commercially.

\section{References}

[1] Gonzalez R, Treasure T, Phillips R, Jameel H, Saloni D. Economics of cellulosic ethanol production: green liquor pretreatment for softwood and hardwood, greenfield and repurpose scenarios. BioResources 2011;6:2551-67.

[2] Gonzalez R, Treasure T, Phillips R, Jameel H, Saloni D, Abt R, et al. Converting Eucalyptus biomass into ethanol: financial and sensitivity analysis in a cocurrent dilute acid process: Part II. Biomass Bioenergy 2011;35:767-72.

[3] Mosier N, Hendrickson R, Dreschel R, Dien B, Bothast R, Welch G, et al. Principles and economics of pretreating cellulose in water for ethanol production. American chemical society national meeting American chemical society. Paper; 2003.

[4] Mosier N, Wyman C, Dale B, Elander R, Lee Y, Holtzapple M, et al. Features of promising technologies for pretreatment of lignocellulosic biomass. Bioresource Technol 2005;96:673-86.

[5] Wyman C. Cellulosic ethanol: a unique sustainable liquid transportation fuel. Mater Res Soc 2008;33.

[6] Wyman C, Dale B, Elander R, Holtzapple M, Ladisch M, Lee Y. Coordinated development of leading biomass pretreatment technologies. Bioresource Technol 2005;96:1959-66.

[7] Wyman CE. Biomass ethanol: technical progress, opportunities, and commercial challenges. Ann Rev Energy Environ 1999;24:189-226.
[8] Aden A, Ruth M, Ibsen K, Jechura J, Neeves K, Sheehan J, et al. Lignocellulosic biomass to ethanol process design and economics utilizing co-current dilute acid prehydrolysis and enzymatic hydrolysis for corn stover. NREL 2002.

[9] Gonzalez R, Phillips R, Saloni D, Jameel H, Abt R, Pirraglia A, et al. Biomass to energy in the Southern United States: supply chain and delivered cost. BioResources 2011;6:2954-76.

[10] Wu X, McLaren J, Madl R, Wang D. Biofuels from lignocellulosic biomass. Sust Biotechnol 2010:19-41.

[11] Goldemberg J. Ethanol for a sustainable energy future. Science 2007;315:808

[12] Goldemberg J, Coelho S, Nastari P, Lucon O. Ethanol learning curve - the Brazilian experience. Biomass Bioenergy 2004;26:301-4.

[13] Pimentel D, Patzek TW. Ethanol production: energy and economic issues related to US and Brazilian sugarcane. Biofuels Solar Wind Renew Energy Sys 2008:357-71.

[14] Gallagher P, Schamel G, Shapouri H, Brubaker H. The internationa competitiveness of the US corn ethanol industry: a comparison with sugar ethanol processing in Brazil. Agribusiness 2006;22:109-34.

[15] RFA. Ethanol, DDGS exports surge; 2010. <http://www.ethanolrfa.org/news/ entry/ethanol-ddgs-exports-surge/> [retrieved 06.10.10].

[16] Leschinsky M, Sixta H, Patt R. Detailed mass balances of the autohydrolysis of Eucalyptus globulus at $170{ }^{\circ} \mathrm{C}$. BioResources 2009;4:687-703.

[17] Taherzadeh M, Karimi K. Pretreatment of lignocellulosic wastes to improve ethanol and biogas production: a review. Int J Mol Sci 2008;9:1621-51.

[18] Amidon T, Liu S. Water-based woody biorefinery. Biotechnol Adv 2009;27:542-50.

[19] Amidon T, Wood C, Shupe A, Wang Y, Graves M, Liu S. Biorefinery: conversion of woody biomass to chemicals, energy and materials. J Biobased Mater Bioenergy 2008;2:100-20.

[20] White R. Effect of lignin content and extractives on the higher heating value of wood. Wood Fiber Sci 1987;19:446-52.

[21] Pu Y, Treasure T, Gonzalez R, Venditti R, Jameel H. Autohydrolysis pretreatment of mixed hardwoods to extract value prior to combustion. BioResources 2011;6.

[22] Hess J, Wright C, Kenney K. Cellulosic biomass feedstocks and logistics for ethanol production. Biofuels Bioprod Bioref 2007;1:181-90.

[23] Stoutenburg R, Perrotta J, Amidon T, Nakas J. Ethanol production from a membrane purified hemicellulosic hydrolysate derived from sugar maple by Pichia Stipitis NRRL Y-7124. BioResources 2008;3:1349-58.

[24] Salam A, Venditti R, Pawlak J, El-Tahlawy K. Crosslinked hemicellulose citratechitosan aerogel foams. Carbohydr Polym 2011;84:1221-9.

[25] Dias M, Cunha M, Jesus C, Rocha G, Pradella J, Rossell C, et al. Second generation ethanol in Brazil: can it compete with electricity production? Bioresource Technol 2011;102:8964-71.

[26] Seabra JEA, Tao L, Chum HL, Macedo IC. A techno-economic evaluation of the effects of centralized cellulosic ethanol and co-products refinery options with sugarcane mill clustering. Biomass Bioenergy 2010;34:1065-78.

[27] Walter A, Ensinas AV. Combined production of second-generation biofuels and electricity from sugarcane residues. Energy 2010;35:874-9.

[28] Reith J, Den Uil H, Van Veen H, De Laat W, Niessen J, De Jong E, et al. Coproduction of bio-ethanol, electricity and heat from biomass residues; 2002. <ftp://130.112.2.45/pub/www/library/report/2002/rx02030.pdf> [retrieved 21.02.12]. 
[29] Horhammer H, Walton S, van Heiningen A. Producing lactic acid from larch in a kraft mill. The 7th Biennial Johan Gullichsen Colloquium, Espoo, Finland; 2009.

[30] Stanton B, Eaton J, Johnson J, Rice D, Schuette B, Moser B. Hybrid poplar in the Pacific Northwest: the effects of market-driven management. J Forest 2002;100:28-33.

[31] Turnbull JH. Use of biomass in electric power generation: the California experience. Biomass Bioenergy 1993;4:75-84.

[32] Confidential. Power production in Southern U.S. Pesonal information. Southern US; 2011.

[33] Metso. Engineering simualtion software. WinGEMS 5.3. Palisade Corporation; 2011.

[34] Humbird D, Davis R, Tao L, Kinchin C, Hsu D, Aden A, et al. Process design and economics for biochemical conversion of lignocellulosic biomass to ethanol. NREL. NREL/TP-5100-47764; 2011.

[35] Metso. A premier process simulation tool; 2012. <http://www.metso.com/ automation/pp_prod.nsf/WebWID/WTB-071105-2256F-85686/\$File/ E837710-WinGEMS.pdf $>$ [retrieved 22.02.12]

[36] Jimenez L, Gonzalez F. Study of the physical and chemical properties of lignocellulosic residues with a view to the production of fuels. Fue 1991;70:947-50.

[37] IEA. Biomass for power generation and CHP; 2007. <http://www.iea.org techno/essentials3.pdf> [retrieved 26.05.11].

[38] EPRI. Program on technology innovation: integrated generation technology options; 2008. <http://www.energync.net/wdocs/2009_Prism_MERGE_Gen Options_Report.pdf $>$ [retrieved 24.05.11].

[39] AOPC. Waste to energy initiative; 2009. <http://www.slideshare.net/ tbliconference/renewable-energy-biomass-power-plant-project> [retrieved 25.05.11]

[40] USACE. Civil works construction cost index system. US Army Corps of Engineers. EM 1110-2-1304; 2000.
[41] Phillips R. Kraft pulp mill CAPEX. Confidential; 2010.

[42] Phillips R. Lignin filter. Factored vendor quote. Confidential; 2010.

[43] Damodaran A. Cost of capital by sector; 2011. <http://pages.stern.nyu.edu/ adamodar/New_Home_Page/datafile/wacc.htm> [retrieved 20.05.11].

[44] USFRS. Selected interest rates. United States Federal Reserve System; 2011. <http://www.federalreserve.gov/releases/H15/update/> [retrieved 20.05.11].

[45] Aden A, Ruth M, Ibsen K, Jechura J, Neeves K, Sheehan J, et al. Lignocellulosic biomass to ethanol process design and economics utilizing co-current dilute acid prehydrolysis and enzymatic hydrolysis for corn stover. NREL. NREL/TP510-3243; 2002

[46] Frederick W, Lien S, Courchene C, DeMartini N, Ragauskas A, Iisa K. Coproduction of ethanol and cellulose fiber from Southern Pine: a technical and economic assessment. Biomass Bioenergy 2008;32:1293-302.

[47] TMS. Timber mart-south market news quaterly. J South Timber Market News. 1st Quarter 2011; 2011.

[48] Palisade. Risk analysis software. @Risk. Palisade Corporation; 2011.

[49] NREL. Lessons learned from existing biomass power plant. National Renewable Energy Lab. NREL/SR-570-26946; 2000.

[50] DOE. ABC's of Biopower; 2011. <http://www1.eere.energy.gov/biomass/ abcs_biopower.html> [retrieved 25.06.11].

[51] NEO. Ethanol and unleaded gasoline average rack prices. Official Nebraska Goverment Website; 2011. <http://www.neo.ne.gov/statshtml/66.html> [retrieved 26.09.11].

[52] Laser M, Jin H, Jayawardhana K, Lynd LR. Coproduction of ethanol and power from switchgrass. Biofuels Bioprod Bioref 2009;3:195-218.

[53] Laser M, Larson E, Dale B, Wang M, Greene N, Lynd LR. Comparative analysis of efficiency, environmental impact, and process economics for mature biomass refining scenarios. Biofuels Bioprod Bioref 2009;3:247-70. 